\title{
Ullmann-Type Coupling of Phenols with Aryl Halides on Cuprian Zeolite USY
}

Polymer-Supported

Synthesis

Key words

copper

zeolites

UlImann reaction

phenols

aryl halides

Typical results:<smiles>Cc1cc(C)cc(Oc2ccccc2)c1</smiles>

$85 \%$ yield $(X=I)$<smiles>CCOc1ccc(Oc2cc(C)cc(C)c2)cc1</smiles>

$84 \%$ yield $(X=I)$

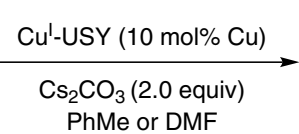

$120-140{ }^{\circ} \mathrm{C}, 24 \mathrm{~h}$<smiles></smiles>

up to $86 \%$ yield<smiles>Cc1cc(C)cc(Oc2ccc([N+](=O)[O-])cc2)c1</smiles>

$83 \%$ yield $(\mathrm{X}=\mathrm{I})$<smiles>Cc1cc(C)cc(Oc2ccccc2C)c1</smiles>

$85 \%$ yield $(\mathrm{X}=\mathrm{I})$<smiles>CCNc1ccc(Oc2cc(C)cc(C)c2)cc1</smiles>

$84 \%$ yield $(\mathrm{X}=\mathrm{Br})$<smiles>Cc1cc(C)cc(Oc2ccc(C#N)cc2)c1</smiles>

$83 \%$ yield $(\mathrm{X}=\mathrm{Br})$<smiles>c1ccc(Oc2ccccc2)cc1</smiles>

$79 \%$ yield $(X=I)$<smiles>Cc1ccc(Oc2ccccc2)cc1</smiles>

$86 \%$ yield $(\mathrm{X}=\mathrm{I})$<smiles>Cc1cc(C)c(C)c(Oc2ccccc2)c1</smiles>

$86 \%$ yield $(X=I)$<smiles>Cc1cc(C)cc(Oc2c(C)cccc2C)c1</smiles>

$34 \%$ yield $(X=B r)$<smiles>Cc1cc(C)c(Oc2ccccc2)c(C)c1</smiles>

$62 \%$ yield $(\mathrm{X}=\mathrm{Br})$<smiles>N#Cc1ccc(OC2=CCCC=C2)cc1</smiles>

$0 \%$ yield $(\mathrm{X}=\mathrm{I})$<smiles>O=[N+]([O-])c1ccc(Oc2ccccc2)cc1</smiles>

$0 \%$ yield $(X=I)$
Significance: Copper(I)-exchanged zeolite USY (CU'-USY) catalyzed the Ullmann-type coupling of phenols with aryl iodides or bromides in the presence of cesium carbonate to give the corresponding diaryl ethers in up to $86 \%$ yield. In the reaction of 3,5-dimethylphenol with iodobenzene, the catalyst was recovered by simple filtration and reused four times without loss of catalytic activity.
Comment: The authors have previously reported a Huisgen cycloaddition and a Glaser coupling with Cu'-USY (Org. Lett. 2007, 9, 883; Eur. J. Org. Chem. 2009, 423). The catalytic activity of $\mathrm{Cu}^{\prime}-$ USY for the Ullmann-type coupling was superior to that of the other $\mathrm{Cu}(\mathrm{I})$ zeolites, such as Cu'-MOR, $\mathrm{Cu}^{\prime}-\beta$, or Cu'-ZSM5. Cu'-USY was ineffective for the reactions of 4-cyano- or 4-nitrophenols with phenyl halides. ICP-AES analysis revealed that no copper leached from the catalyst during the reaction. 